\title{
AKADEMICKI KOLONIALIZM. SYTUACJA HOLOCAUST STUDIES W POLSCE ${ }^{1}$
}

\author{
PAWEE WOLSKI ${ }^{2}$ \\ (Uniwersytet Szczeciński)
}

\begin{abstract}
Słowa kluczowe: literatura Zagłady, badania porównawcze, badania postkolonialne
\end{abstract}
Key words: Holocaust literature, comparative studies, postcolonial studies

\begin{abstract}
Abstrakt: Paweł Wolski, AKADEMICKI KOLONIALIZM. SYTUACJA HOLOCAUST STUDIES W POLSCE. „PORÓWNANIA” 13, 2013, t. XIII. s. 81-91. ISSN 1733-165X. Polskie badania nad literaturą Zagłady toczą się od dawna, dyscypliną stały się jednak niedawno. Nie jest to jedynie wynikiem późnego wykształcenia się instytucjonalnych ram tego nurtu badań, ale przede wszystkim jego zanurzenia w innych nurtach, np. w badaniach nad „literaturą wojny i okupacji”. Przekształcanie się polskiego literaturoznawstwa zajmującego się m.in. Holocaustem $\mathrm{w}$ literaturoznawstwo holocaustowe, tj. Holcaust studies, zachodziło przy tym $\mathrm{w}$ otoczeniu uformowanej już gdzie indziej - $w$ tym przede wszystkim w USA - dyscypliny. Paradoks współczesnego etapu formowania się tego obszaru badań w Polsce polega więc na tym, że przyjmuje ono z zewnątrz wzorce, które istnieją w nim już od dawna. Proces ten w niniejszym tekście nazywam akademickim (auto)kolonializmem i wskazuję jego najważniejsze cechy.
\end{abstract}

\begin{abstract}
Paweł Wolski, ACADEMIC COLONIALISM. HOLOCAUST STUDIES IN POLAND "PORÓWNANIA" 13, 2013, Vol. XIII, p. 81-91. ISSN 1733-165X. The study of the Holocaust literature in Poland goes a long way back but as a separate discipline it has existed for a very short time. This is mostly due to the fact that until recently it had been part of other fields of study, including, mostly, war literature. A specific feature of this process is that the transformation from literary studies dealing with the Holocaust as one of the themes of proper Holocaust (literary) studies in Poland has been developing under strong influence of foreign - mainly American - Holocaust studies as an already evolved discipline. Therefore, Polish Holocaust studies have practically assumed the shape it has already had, but under a different name. In the paper I call this process academic (auto)colonialism and make an attempt to indicate its core features.
\end{abstract}

1 Projekt został sfinansowany ze środków Narodowego Centrum Nauki przyznanych na podstawie decyzji numer DEC-2011/03/D/HS2/02781.

2 Correspondence Address: wolski@op.pl 
Sytuacja holocaustowego literaturoznawstwa wygląda, zdaniem Davida Roskiesa, autora jednej z najnowszych przyczynków do tej dziedziny, tak:

Wydanie Holocaust Literature, liczącej 1500 stron encyklopedii obejmującej 309 autorów i napisanej przez międzynarodowy zespół 122 badaczy, powinno być świetną okazją, aby zrobić dla tej literatury to, co tak dobrze zrobiono dla zbiorowej pamięci o Wielkiej Wojnie.

Oby tak rzeczywiście było! Zamiast (...) podążać od przeszłości do teraźniejszości, zamiast uratować dla anglojęzycznego czytelnika tych pisarzy, którzy zginęli, zamiast posuwać się systematycznie z wnętrza każdej kultury, zamiast dostarczyć opisowe kompendium, ta encyklopedia podąża od teraźniejszości i zmierza wstecz: tzn. wybór autorów, umiejscowienie i żargon krytycznoliteracki wyrażają obecną modę intelektualną, przede wszystkim w Ameryce Północnej. O doborze autorów zadecydowały w znacznej mierze względy ideologiczne. Pisarz, który mieszka w postkolonialnej Australii czy Brazylii, nawet jeśli napisał tylko jedną książkę dotyczącą Holokaustu, miał większą szansę znalezienia się w encyklopedii niż ten, który zginął w Auschwitz czy Białymstoku ${ }^{3}$.

A wszystko to wina - Anne Frank. Cytuję tym razem polskiego komentatora:

Przypadek Dziennika Anny Frank jest na tyle istotny, że warto mu tu poświęcić więcej miejsca. Zapiski te opublikowano po raz pierwszy w Holandii w 1947 roku, trzy lata później ukazało się ich francuskie i niemieckie tłumaczenie. W Niemczech sprzedano jednak zaledwie 4,5 tysiąca egzemplarzy, a publikacja przeszła bez echa. Co jednak z perspektywy czasu ważne - nie było na nią reakcji negatywnych. Książka spotkała się raczej z obojętnością, niż odrzuceniem, jak miało to miejsce $\mathrm{w}$ przypadku filmów dokumentalnych o obozach koncentracyjnych z lat 1945-47, wyświetlanych przez aliantów w ramach denazyfikacji. Światowa popularność książki Anny Frank była dopiero następstwem amerykańskiego sukcesu adaptacji scenicznej z 1955 roku autorstwa Goodricha i Hacketta [sic!]. Sztuka oparta o tekst Dziennika nie eksponowała, jak można dziś zauważyć, tego, co wskazuje na partykularny, żydowski los Anny, co wyraźnie ułatwiło ówczesnej widowni amerykańskiej identyfikację z jej osobą. (...) Przypadek tej adaptacji pozwala sobie uświadomić granice akceptowalnej reprezentacji Shoah w połowie lat 50. Światowy rozgłos tej sztuki i jej wpływ na społeczną pamięć o zagładzie można potraktować jako wczesną zapowiedź „amerykanizacji Holocaustu”, zjawiska wiązanego przez większość badaczy z dekadą lat 80 . i $90 .{ }^{4}$

${ }^{3}$ David Roskies jest współautorem (wraz z Naomi Diamant) wydanej pod koniec 2012 roku książki Holocaust Literature. A History and Guide (Waltham 2012), w której nawiązuje do przywoływanej przeze mnie tezy na stronie 6 . Powyższy cytat pochodzi jednak z wcześniejszego, tłumaczonego na język polski eseju, który później w zmodyfikowanej wersji znalazł się w książce: D.G. Roskies, Czym jest literatura Holokaustu? Przeł. M. Adamczyk-Garbowska, „Literatura na Świecie” 2005, nr 9-10, s. 239-240.

${ }^{4}$ T. Majewski, Dyskurs publiczny po Shoah. W: Pamięć Shoah. Kulturowe reprezentacje i praktyki upamiętniania. Red. T. Majewski, A. Zeidler-Janiszewska. Współpraca red. M. Wójcik. Łódź 2009, ss. 237-238. Scenarzyści, o których wspomina Tomasz Majewski, to Frances Goodrich i Albert Hackett, a zatem odpowiedni fragment powinien raczej brzmieć "Goodrich i Hacketta”. 
Nie tyle o „amerykanizację" mi tu jednak będzie chodzić. Przede wszystkim dlatego, że temat ten zdaje się już wyczerpany, m. in. przez Petera Novicka ${ }^{5}$. Bardziej interesujący wydaje mi się niemal niezauważalny wpływ pewnego paradygmatu badań nad literaturą, zmieniający sposób funkcjonowania literaturoznawstwa w ogóle i otwierający tym samym możliwość zaistnienia literaturoznawstwa holocaustowego. Mam na myśli liczne przełomy, czy zwroty, będące, według diagnozy Danuty Ulickiej, powtórzeniem odkryć wschodnioeuropejskich ${ }^{6}$ (Kuhn to powtórzony Ludwik Fleck, narratywizm to powtórzony Propp, a intertekstualizm Kristevej to polifoniczność Bachtina itd.), które są przy tym użyteczną okolicznością ułatwiającą ukazanie sposobu przechodzenia polskiego literaturoznawstwa zajmującego się literaturą wojny, okupacji i Zagłady w literaturoznawstwo holokaustowe. Czyli, innymi słowy: dobrowolnego nałożenia na istniejącą już akademicką strukturę wzorca dyscyplinarnego istniejącego gdzie indziej, swoisty akademicki auto-kolonializm.

Funkcjonowaniem współczesnych badań nad literaturą Holocaustu - które odróżniam od wcześniejszych badań nad literaturą wojny i okupacji - rządzą dwa komplementarne wobec siebie gesty - identyfikacji i separacji. Sprawę identyfikacji wyjaśnię na przykładzie, który biorę od Amy Hungerford, autorki książki o znaczącym tytule: Holokaust tekstów ${ }^{7}$. Badaczka otwiera ją anegdotą ukazującą wspomnianą przez Majewskiego drogę dziennika Anne Frank na Broadway a potem do kanonu holokaustowej literatury. Meyer Levin, autor odrzuconej scenicznej adaptacji Dziennika, spożytkował podobno wszelkie możliwe sposoby wpłynięcia na Broadwayowskich producentów, zużył wszystkie możliwe argumenty mające zmienić ich zdanie, aż wreszcie odwołał się do publicznej moralności. Opublikował w „NY Post” list otwarty, w którym zwracał się do Kermita Bloomgardena (producenta zaakceptowanej sztuki) i Ottona Franka (ojca Anne) tymi oto słowami: „Czy to jest w porządku, tak mordować wzruszającą sztukę (...)?8." Pisał też do czytelników: „Wyślijcie ten tekst do Ottona Franka i Bloomgardena (...) jako głos oburzenia przeciw mordowaniu mojej sztuki9." Sam słał ponadto niezliczone listy do Franka i Bloomgardena, w których zrównywał los Anne i jego adaptacji jej dziennika, pisząc, że i ona i tekst zasługują na „normalne życie i normalną śmierć" 10 .

Ta obsesyjna antropomorfizacja tekstu jest, zdaniem A. Hungerford, zasadniczym wyznacznikiem literatury Zagłady: autorzy holokaustowych tekstów -

${ }^{5}$ P. Novick, The Holocaust in American Life. Boston 1999.

${ }^{6}$ D. Ulicka, Literaturoznawcze dyskursy możliwe: studia z dziejów nowoczesnej teorii literatury w Europie Srodkowo-Wschodniej. Kraków 2007.

7 A. Hungerford, The Holocaust of Texts: Genocide, Literature, and Personification. Chicago 2003.

8 Ibidem, s. 1.

9 Ibidem [pogrubienie - P.W.].

${ }^{10}$ Ibidem, s. 2. 
dzienników z czasów wojny, pamiętników, zapisków, ale też powojennych adaptacji cudzych tekstów czy posttraumatycznych powieści i komiksów - ulegają tak silnej identyfikacji ze swoim zapisem, że traktowanie życia i śmierci tekstu jako własnego życia i własnej śmierci staje się czymś w tym typie literatury powszechnym. Pożyczam tę tezę od Hungerford z dwóch powodów: po pierwsze, bo dzięki Annie Frank pokazuje zachodnią genezę tego wyznacznika (chodzi nie tylko o Broadway, ale także o renesans zainteresowania tekstem holenderskiej dziewczynki dzięki lekturom Lejeune'a ${ }^{11}$ ), po drugie zaś dlatego, że gdy ją nieco poszerzyć - ukazuje zasadniczy sposób funkcjonowania akademickiego pisarstwa Zagłady.

Otóż identyfikacja, o której pisze Hungerford, działa również w tym właśnie akademickim - typie pisarstwa holokaustowego. Jerozolimska konferencja pt. „Sine Ira et Studio? Personal Engagement, Historical Distance and the Study of the Holocaust" 12 dowodzi zresztą, że jest to zjawisko zauważalne już na metaakademickim poziomie. Warto przyjrzeć mu się bliżej, tym bardziej, że jest to fenomen, który czasem zachodzi w dość paradoksalny, niemal niezauważalny sposób. Berel Lang na przykład zaczyna fundamentalną dla dziedziny Holocaust studies rozprawę - "Akt i Ideę" - od wyjaśnienia, że czuje związek z Zagładą, ponieważ... nie ma związku z Zagładą"

Sam nie zostałem bezpośrednio dotknięty przez nazistowskie ludobójstwo. Urodziłem się w Stanach Zjednoczonych, pod koniec 1933 roku i przez następne 12 lat, podczas których powstały i upadły hitlerowskie Niemcy, społeczność żydowska małego miasteczka w Connecticut, gdzie mieszkałem, nie wiedziałem, lub w każdym razie nie zwracała większej uwagi na to, co zdarzyło się Żydom w Europie ${ }^{13}$.

Tym samym Lang wyraża jednak przekonanie (wyraźne w dalszych częściach tej ważnej książki), że mówić o Zagładzie mogą tylko lub choćby przede wszystkim ci, którzy się jakoś z nią - i z mówieniem o niej - identyfikują, nieważne: afirmacyjnie czy negatywnie.

Z kolei Lucy Dawidowicz zaczyna swoją Wojne przeciw Żydom, jedną z pierwszych historiograficznych rozpraw należących do zinstytucjonalizowanej dziedziny Holocaust studies, a jednak głęboko jednak zanurzoną $\mathrm{w}$ paradygmacie historiografii „Rankowskiej”, tj. żywiącej podskórne przekonanie o tym, że historyk jest neutralnym przekazicielem faktów, od takich oto słów: „To nie jest książka stroniąca od wartościowania. Sam temat Ostatecznego Rozwiązania wyklucza neu-

11 P. Lejeune, W jaki sposób Anne Frank napisała na nowo dziennik Anne Frank. Przeł. M. i P. Rodakowie, „Pamiętnik Literacki” 2002, z. 2. Tekst był po raz pierwszy zaprezentowany podczas konferencji „Le journal personnel” w Nanterre 19 maja 1990 roku.

$12 \mathrm{http}$ // / www.dhi.waw.pl/pl/imprezy/event/event/sine-ira-et-studio-personal-engagementhistorical-distance-and-the-study-of-the-holocaust.html?no_cache=1.

${ }^{13}$ B. Lang, Nazistowskie ludobójstwo. Akt i idea. Przeł. A. Ziębińska-Witek. Lublin 2006, s. 19. 
tralność. Żeby pisać o narodzie, który złamał przykazanie „Nie zabijaj”, trzeba stanąć naprzeciw stanowisku, które Charles Beard nazwał "neutralnym, lustrzanym odbiciem'14." Dawidowicz zaczyna więc swoją historiograficzną narrację w sposób nie tylko mało charakterystyczny dla konwencjonalnej historiografii, ale wręcz ustala osobność quasi-historiograficznego gatunku, który uprawia, pisząc, że nie można być obiektywnym w obliczu Zagłady i dlatego - jak wnioskujemy mówiąc o Holocauście, musi, choć nie chce, mówić o sobie. Taką postawę najdobitniej wyraża jednak Lori Lefkovitz, badaczka z Northeastern University, wyjawiając, że „pytana o rodzinę odpowiada zawsze, że jej matka spędziła wojnę na Syberii; ale jako że Syberia to - jak mówi dalej - coś w rodzaju 'pogranicza ocalonych', natychmiast dodaje też, że jej ojciec był w Auschwitz i Buchenwaldzie ${ }^{15}$." Ta posttraumatyczna i fatazmatyczna identyfikacja bardzo przypomina wywód Sue Vice, która w książce Holocaust Fiction przywołuje dowody na tezę zbliżoną do tego, co w cytowanej już The Holocaust of Texts ${ }^{16}$ pisała Hungerford: że w tym typie pisarstwa istnieje bezpośredni - być może bardziej bezpośredni niż gdzie indziej, niemal cielesny - związek między autorem i jego tekstem. Otóż Sue Vice wyjaśnia, że dyskusje wokół przedstawialności Zagłady często koncentrowały się na czymś, co autorka nazwała "skandalami”, z których autorzy "skandalicznych" tekstów musieli się tłumaczyć. Na przykład Benigni po nakręceniu Życie jest piękne objaśniał swoje prawo do mówienia o Zagładzie tym, że jego ojciec był w obozie pracy17, a Styron po napisaniu Wyboru Zofii w odpowiedzi na krytykę podkreślał, że ma żydowskie potomstwo ${ }^{18}$. Zresztą Wybór Zofii uczynił z niego Żyda i przez to potomka ocalonych niezależnie od pochodzenia żony czy dzieci: jak głosi anegdota, Truman Capote miał powiedzieć kiedyś: „Jeśli istnieje coś takiego jak żydowski goj, to jest nim właśnie Styron ${ }^{19}$." Identyfikacja z tekstem jako wyznacznik - nie dopowiadam: genologiczny, bo to rzecz na osobny wątek - dotyczy więc każdego typu tekstów o Zagładzie: filmów, komiksów, powieści i akademickich rozpraw.

Jak wspominałem, temu gestowi identyfikacji z własnym tekstem towarzyszy gest inny: odróżnienia własnej dziedziny od dziedzin okolicznych. Cytuję na dowód tekst z czasów rozkwitu tej dziedziny na Zachodzie, tj. Podwójna śmierć amerykańskiego badacza Alvina Rosenfelda: „Literatura Holocaustu stanowi zupełnie inny wymiar pisarstwa -nieograniczone do określonej tematyki, zmusza nas ono

${ }^{14}$ L. S. Dawidowicz, The War Against the Jews, 1933-1945. New York 1986, p. XL.

${ }_{15}$ Cyt. za: G. Weismann, Fantasies of Witnessing. Postwar Efforts to Experience the Holocaust. Ithaca and London 2004, s. 21. Autor ma na myśli następujący tekst Lori Lefkovitz: L. H. Lefkowitz, Inherited Holocaust Memory and the Ethics of Ventriloquism. W: Shaping Losses: Cultural Memory and the Holocaust. Red. J. Epstein i L. H. Lefkovitz. Urbana 2001, p. 223.

16 A. Hungerford, The Holocaust of Texts: Genocide, Literature, and Personification. Chicago 2003.

17 Ibidem, p. 255.

18 Ibidem, p. 254.

${ }_{19}$ Cyt. za: E. Volkman, A Legacy of Hate. Anti-Semitism in America. New York, London, Toronto, Sydney 1982, p. 96. 
do rozważenia fundamentalnej zmiany naszego sposobu percepcji i ekspresji: do przyjrzenia się naszemu odmiennemu sposobowi bycia w świecie" 20 .

Rezygnuję z innych przykładów podobnych zjawisk w zachodnich Holocaust studies, żeby odnieść to do sprawy polskiej, a potem - do próby wyjaśnienia, jak to wszystko się ma do aktualnego stanu tej dziedziny. Otóż trudniej o podobne przykłady i cytaty z naszej dyskusji akademickiej z owych czasów. Z kilku powodów: Holocaust studies $\mathrm{w}$ zinstytucjonalizowanej formie, jaką mamy na myśli dziś, w Polsce w latach siedemdziesiątych, osiemdziesiątych właściwie istniały jedynie zalążkowo, a i te zalążki były raczej częścią innych badań: historiografii, literaturoznawstwa itp. Sama publiczna debata nad Zagładą, owszem, istniała: pomijam tymczasem np. sprawę Borowskiego, ale można by zauważyć, że „Kultura" już przecież w roku 1956 zamieściła ankietę dotyczącą antysemityzmu. I że w tle tej ankiety kryło się pytanie o Holocaust i współczesne postawy Polaków wobec niego (a w każdym razie nieliczne odpowiedzi niezmiennie ciążyły ku te$\mathrm{mu}$ tematowi). Tyle tylko, że antysemityzm zaledwie kryptonimuje $\mathrm{w}$ tej ankiecie rzeczywistą rozmowę o niemieckich zbrodniach w Polsce, która nie była nawet zasadniczym powodem jej przeprowadzenia, a pojawiała się $\mathrm{w}$ reakcjach ankietowanych jako argument pomocniczy, a nie temat, którym były raczej wydarzenia polityczne 1956 roku.

Słowami samych redaktorów pisma:

Wyniki ankiety „Kultury” o polskim antysemityzmie są skromne. Prawie żadnej odpowiedzi od osób, które poprosiliśmy o wypowiedzenie się w tej sprawie. Przyczyny tego milczenia mogą być oczywiście różnorodne: niechęć do „Kultury”, brak czasu, niechęć do zbyt może rozpowszechnionych dziś ankiet... Jest to jednak pierwszy wypadek, aby tego rodzaju inicjatywa podjęta przez „Kulturę" spotkała się z tak negatywną reakcją ${ }^{21}$.

Oczywiście dokonane przez redakcję wyliczenie powodów negatywnej lub obojętnej reakcji respondentów zostało zamieszczone na prawach elipsy: powody niechęci znajdowały się zupełnie gdzie indziej. Pominę je i ja22, stwierdzając jedynie, że tak postrzegane wyniki ankiety potwierdzają opinię, że zarówno polska debata publiczna wokół Holocaustu, jak i jej wątki w literaturze, to okres dużo późniejszy. Dopiero zatem teksty takie jak O sytuacji pisarza polskiego pochodzenia żydowskiego

${ }^{20}$ A. H. Rosenfeld, Podwójna śmierć: rozwazania o literaturze Holocaustu. Przeł. B. Krawcowicz, Warszawa 2003, s. 26. W USA książka ukazała się po raz pierwszy w roku 1980.

${ }^{21}$ Problem antysemityzmu. Ankieta „Kultury” [podpis pod tekstem: „REDAKCJA”]. „Kultura” 1957, nr $1 / 2$, s. 56 .

${ }^{22}$ Niektóre z nich wymienia - wpisując $\mathrm{w}$ to wyliczenie znaną tezę niejako określającą z góry możliwe wyniki rozważań - Jan Tomasz Gross w eseju "Ten jest z Ojczyzny mojej...” ale go nie lubie (J. T. Gross, "Ten jest z Ojczyzny mojej..." ale go nie lubię. W: idem, Upiorna dekada. Trzy eseje o stereotypach na temat Żydów, Polaków, Niemców i komunistów 1939-1948. Kraków 2001). 
$w$ XX wieku Sandauera ${ }^{23}$ z 1982 roku, sygnują to, co nazwać można zalążkami polskich badań nad Holocaustem. Poza tekstem Sandauera są to wydarzenia takie jak cytuję Przemysława Czaplińskiego:

w 1986 (...) Poczatek Andrzeja Szczypiorskiego i Sublokatorka Hanny Krall; w 1987 - esej Jana Błońskiego Biedni Polacy patrza na getto, Weiser Dawidek Pawła Huellego, Zagłada Piotra Szewca, Kadysz Henryka Grynberga, Teatr zawsze grany Adolfa Rudnickiego, wznowienie Pamiętnika Dawida Rubinowicza w opracowaniu Zygmunta Hoffmana; w 1988 - Umschlagplatz Jarosława Marka Rymkiewicza... ${ }^{24}$

oraz - dodajmy - wydana w 1988 roku antologia Ireny Maciejewskiej25 czy tematyczny numer "Znaku”26, mający być "naszym rachunkiem sumienia” i który ma za zadanie „przerzucać pomosty zarówno pomiędzy nowymi pokoleniami Polaków a zaginionym światem Żydów Polskich"27.

Można jednak mówić o wcześniejszym istnieniu czegoś, co nazwę polskim literaturoznawstwem holocaustowym avant la lettre. To na przykład Literatura wobec wojny $i$ okupacji, wydana w latach siedemdziesiątych zbiorowa praca autorów mierzących się z tematem wojny, "obozu koncentracyjnego czy konspiracji”28. Ostatnie kilka słów to cytat ze wstępu Janusza Sławińskiego, który wymienia te zagadnienia właśnie $\mathrm{w}$ takim, charakterystycznym porządku. Charakterystycznym, bo polskie literaturoznawstwo $\mathrm{w}$ latach sześćdziesiątych i później krytptonimowało w ten sposób polskie pierwociny literaturoznawstwa Holocaustu, którym jednak brakuje zasadniczych elementów niezbędnych temu, by zaliczyć je do Holocaust studies takich, jak rozumiemy je dziś. Pierwszym z tych elementów jest oczywiście

${ }^{23}$ A. Sandauer, O sytuacji pisarza polskiego pochodzenia żydowskiego w XX wieku. (Rzecz, którą nie ja powinienem napisać...). Warszawa 1982.

${ }^{24}$ P. Czapliński, Prześladowcy, pomocnicy, świadkowie. Zagłada i polska literatura późnej nowoczesności. W: Zagłada..., op. cit., ss. 155-156.

${ }^{25}$ Męczeństwo i zagłada Żydów w zapisach literatury polskiej. Red. I. Maciejewska. Warszawa 1988.

26 S. Wilkanowicz, Antysemityzm, patriotyzm, chrześcijaństwo. „Znak” 1983, nr 2-3.

${ }^{27} \mathrm{~W}$ całości artykuł ten jeszcze wyraźniej opisuje stan ówczesnej dyskusji na ów temat: „Jeśli nasze pojmowanie funkcji literatury jest kształtowane przez poczucie zagrożenia narodowej identyczności (...), [j]eżeli w naszej kulturze nurt katastroficzno-heroiczny splata się z przekornym śmiechem (...), to czy Żydzi nie są zmuszeni do tego samego? (...) [T]rzeba więc przerzucać pomosty zarówno pomiędzy nowymi pokoleniami Polaków a zaginionym światem Żydów Polskich, jak też współczesną myślą żydowską, podejmującą centralne zagadnienia bytowania człowieka w przestrzeni pomiędzy miłosierdziem Boga a obszarami szczególnej kondensacji sił nienawiści, których niezwykłym wyrazem był holokaust - eksterminacja biblijnie przez żydów nazywana całopaleniem" (S. Wilkanowicz, Antysemityzm, patriotyzm, chrześcijaństwo. "Znak”, op. cit., s. 175). Przy tej okazji zupełnie marginalnie można zwrócić uwagę na niezakorzenienie się jeszcze terminu Holocaust, tu pisane 1) wielką literą i 2) wyjaśniane w sposób bezproblemowy, bo bez świadomości późniejszych sporów na temat samego terminu i jego egzegezy biblijno-teleologicznej.

${ }_{28} \mathrm{~J}$. Sławiński, Zaproszenie do tematu. W: Literatura wobec wojny i okupacji. Red. M. Głowiński i J. Sławiński. Wrocław 1976, s. 8-9. 
instytucja - której w postaci uniwersyteckich katedr, muzeów itp. zajmujących się tylko lub przede wszystkim Zagładą wówczas brakło (Muzeum w Auschwitz i polityczne konteksty jego funkcjonowania to temat na osobną rozprawę, a działalność ŻIH-u jako instytutu przede wszystkim historycznego z tego i innych powodów zostawiam tymczasem na boku). Kolejne elementy to wyznaczniki, o których mówiłem. Dzisiejsze polskie badania nad literaturą Zagłady, oprócz instytucji, takich jak Centrum Badań nad Zagładą Żydów przy PAN czy istniejącej od bardzo niedawna sekcji do badania literatury przy Żydowskim Instytucie Historycznym, mają bowiem pewną schizofreniczną i opartą właśnie na tych wyznacznikach samoświadomość, nieobecną $\mathrm{w}$ tych nurtach literaturoznawstwa, które uznać można za prefiguracje polskich Holocaust studies. Schizofreniczność tej samoświadomości polega na jednoczesnym wymaganiu od świadków obiektywności (której symbolem stał się np. naukowy język Primo Leviego) i identyfikacji z tekstem, tzn. jednoczesnego pisania o nagich, niezakłamanych faktach, niejako z zewnątrz, i pisania z osobistej, poświadczającej naoczność perspektywy - tj. $\mathrm{z}$ wewnątrz wydarzeń. Literaturoznawstwo wcześniejsze domagało się tylko tego pierwszego, tj. obiektywizmu - rzecz jasna niemożliwego, ale istniejącego jako postulat i, tym samym, wyznacznik. Tak pisał o tym we wstępie do Literatury wobec wojny i okupacji cytowany już Janusz Sławiński: młodego badacza tych zagadnień nie powinny „pętać uczuciowe zobowiązania wobec tematu” ${ }^{29}$ wojny, „obozu koncentracyjnego i konspiracji".

Rzecz jasna, pisanie o tym wyzbywaniu się jest lustrzanym odbiciem gestu identyfikacji, pokazującym przynajmniej tyle, że omawiany problem istnieje, tyle tylko, że w tej wersji literaturoznawstwa (którego ramy wyznacza epistemologia strukturalistyczna) trzeba go ignorować. Bo i to, o czym piszę, jest okolicznością tego typu literatury do pewnego stopnia niezależną od aktualnych stylów jej czytania. Mówiąc inaczej: jest tak, że istnieje w tej literaturze coś, co wymusza na literaturoznawstwie zajmującym się nią pewne reakcje, a nie tylko tak, że to literaturoznawstwo tworzy status tej literatury (jest charakterystyczne, że spośród wszelkich szkół literaturoznawczych, wywierających wpływ na tę dziedzinę: od feminizmu, przez dekonstrukcję po animal studies, Jaussowski horyzont oczekiwań czytelniczych albo radykalny konstruktywizm nie utorowały sobie dotąd do niej drogi). Dość przypomnieć, że właśnie o umieszczenie siebie w tekście chodziło $\mathrm{w}$ jednej z pierwszych polskich quasi-literaturoznawczych dyskusji wokół przedstawialności Zagłady: Alicję w krainie czarów, recenzję-esej Tadeusza Borowskigo wymierzony w Z otchłani Zofii Szczuckiej można streścić w słowach „Opowiedzcie (...), że właśnie wyście to robili"30: nie opisujcie Zagłady, ale opisujcie siebie w Zagładzie.

${ }^{29}$ Ibidem, s. 7.

${ }^{30}$ T. Borowski, Alicja w krainie czarów. W: T. Borowski, Pisma w czterech tomach. Red. T. Drewnowski, J. Szczęsna, S. Buryła, t. 4: Krytyka. Red. T. Drewnowski, Kraków 2005, s. 86 (pierwodruk: „Pokolenie" 1947, nr 1). 
To jednak wciąż za mało, żeby uznać ówczesne polskie badania literaturoznawcze nad Zagładą za tożsame $\mathrm{z}$ badaniami dzisiejszymi (albo, żeby nie waloryzować: dzisiejsze z ówczesnymi). Dzisiejsze literaturoznawstwo holokaustowe charakteryzuje się bowiem jeszcze co najmniej jednym wyznacznikiem: wyraźnym dążeniem do uformowania się $\mathrm{w}$ autonomiczną dziedzinę. Sprawę tę pokażę krótko na przykładzie Roberta Eaglestone'a, który zresztą rozpoczyna swoją rozprawę Holocaust i postmoderna ${ }^{31}$ od bliskiej temu, co tu mówiłem, tezy: od kwestii identyfikacji autora $\mathrm{z}$ własnym tekstem. Tyle tylko, że jego zdaniem ta identyfikacja $\mathrm{w}$ tekstach Zagłady istnieje $\mathrm{w}$ sensie negatywnym, tj. techniki narracyjne, które trzeba uznać za charakterystyczne dla tego gatunku, dążą do ustanowienia dystansu wobec opisywanych zdarzeń,. W efekcie teksty Zagłady "prowadzą do identyfikacji i, jednocześnie, odrzucają ją"32. A robią to za pomocą kilku wymienianych przez autora technik, takich jak: po pierwsze - „używanie historii”, czyli używanie "historiograficznego stylu", dołączanie dokumentów, zdjęć itp. przedmiotów do narracji, od których zazwyczaj nie oczekuje się takich gestów (wymienia np. listy do niemieckiego czytelnika zamieszczone $\mathrm{w}$ przekładach Czy to jest człowiek Leviego) itd.; po drugie - „rama narracyjna”, za pośrednictwem której autor jednocześnie włącza czytelnika do narracji i zaznacza jego obcość, np. poprzez zastosowanie przez Leviego formy eseju uspójnionego narracją (bo esej, jak zauważa Eaglestone, to forma $\mathrm{z}$ definicji fragmentaryczna i przez to markująca chwilowość identyfikacji); po trzecie i po kolejne - „epifanie”, czyli momenty szczególnego nagromadzenia scen okrucieństwa zatrzymujące tym samym narrację, potem jeszcze brak domknięcia narracji i kilka innych elementów, które składają się, zdaniem Eaglestona, na, jak zaznacza, niekompletny, ale „wyraźny zestaw technik narracyjnych" charakteryzujących opowieści o Zagładzie itd. ${ }^{33}$

Eaglestone to profesor literatury i myśli współczesnej na uniwersytecie Royal Halloway w Londynie. Wspominam o tym, bo trudno byłoby się tego domyślić po przywołanym przeze mnie fragmencie: brak w nim klasycznej terminologii literaturoznawczej (nieobcej autorowi, który napisał akademicki podręcznik teorii literatury). Coś tu, mówiąc krótko, nie gra. Jest to dysonans pomiędzy językiem opisu literatury i językiem opisu literatury Zagłady. Weźmy tylko dwa pierwsze przykłady: „używanie historii” - „using history" - to po prostu stosowanie historycznych tropów. Anglojęzyczne literaturoznawstwo ma na to ustabilizowane terminy takie jak np. emplotment w rozumieniu Haydena White'a, o których nie wspomina Eagelstone. Dalej: „rama narracyjna” w oryginale to "narrative frame”, termin oznaczający po prostu „kompozycję szkatułkową", o którą, jeśli dobrze rozumiem dalszy opis, Eagelstonowi wcale nie chodzi. Wiele by można jeszcze powiedzieć

\footnotetext{
31 R. Eaglestone, The Holocaust and the Postmodern. Oxford 2004.

32 Ibidem, s. 43.

${ }^{33}$ Ibidem, s. 43-68.
} 
o "epifaniach" i innych egzotycznych terminach (autorowi chodzi o coś zbliżonego do aporii, której należałoby się raczej spodziewać w książce odwołującej się w tytule do postmodernizmu), ale najważniejsza jest sama zasada, która spaja te pozornie kakofoniczne elementy dobrej skądinąd książki. Otóż literaturoznawstwo Zagłady, niezależnie od perspektywy, z której przygląda się swojemu tematowi tworzy własną aparaturę pojęciową, czyli dąży do separatyzmu, o którym mówiłem. Holocaust studies zauważyły tę zależność już dawno: Andrè Bernstein podkreśla, że pisząc o Zagładzie badacze poświęcają wiele wysiłku „tworzeniu i uzasadnianiu odrębnego, niemal specjalistycznego słownictwa, któremu można potem przypisywać przywilejowany, moralno-intelektualny status, którego najwyraźniej ma braknąć w innych sformułowaniach" 34 . Polskie przykłady wzięte ze współczesnego literaturoznawstwa można by mnożyć - weźmy np. samaleanctum u Barbary Engelking - ale ograniczę się do jednego. Michał Głowiński, jako autor fundamentalnego polonistycznego artykułu Cztery typy fikcji narracyjnej35, odwołuje się do teorii aktów mowy pokazując, jak fikcja narracyjna działa w języku codziennym, czyli, jak można by wywnioskować: wszędzie, i jak stwarza modele komunikacji; ale już jako autor wstępu do Stosowności i formy, książki bez wątpienia sytuującej się $\mathrm{w}$ ramach współczesnej dziedziny Holocaust studies, pisze: „literatura faktu nie ma prawa przechodzić w literaturę operującą fikcją: gdy to się dzieje $\mathrm{w}$ mniej drastycznych przypadkach, powstają zakłócenia, a w najgorszych - mamy do czynienia z oszustwem"36. Są to dwie skrajnie odmienne postawy, ale, co ciekawe, nie jest to żaden dysonans albo niekonsekwencja; przeciwnie: jest to zastosowanie języka opisu adekwatnego do dyscypliny, w której został ulokowany.

Danuta Ulicka w licznych tekstach pokazuje ten typ kolonializmu, o którym chcę napisać $\mathrm{w}$ niniejszym tekście i który uformował sposób badania literatury Zagłady w Polsce. Mówiąc krótko: jakkolwiek polski strukturalizm nigdy nie był hermetycznym monolitem (a silnie podkreślają to zarówno Michał Głowiński, jak i Edward Balcerzan, a Janusz Sławiński dodaje jeszcze, że ten niemonolit nie tylko nie odszedł $\mathrm{w}$ niepamięć, ale że zostało nam po nim $\mathrm{w}$ dzisiejszych naukach humanistycznych wiele), to właściwie jego niemonolityczność ujrzeć można dopiero z perspektywy zwrotów, które wtórnie uświadomiły nam wielowątkowość polskiego i wschodnioeuropejskiego literaturoznawstwa, w tym literaturoznawstwa powojennego. Jedną z ważniejszych lekcji literaturoznawstwa jest lekcja Bachtinowska, ukazująca wewnętrzną polifoniczność istnienia każdego pisarstwa, w tym

${ }^{34}$ A. Bernstein, Hommage to the Extreme: The Shoah and the Rhetoric of Catastrophe. „Times Litterary Supplement" 1998, nr 6, p. 6.

${ }^{35}$ M. Głowiński, Cztery typy fikcji narracyjnej. W: Teoretycznoliterackie tematy i problemy. Red. J. Sławiński. Wrocław 1986.

${ }^{36}$ M. Głowiński, Wprowadzenie. W: Stosowność i forma: jak opowiadać o Zagładzie? Red. M. Głowiński. Kraków 2005, s. 10. 
akademickiego, w którym można identyfikować się z tekstem, jednocześnie będąc tego tekstu metatekstowym komentatorem. W ten sam sposób wyłonienie się badań nad Zagładą umożliwia istnienie dwóch, a może nawet trzech Michałów Głowińskich: poetologicznego, zagładoznawczego i literackiego, którzy, należąc do różnych dziedzin, nie przeczą swoim istnieniom. Ten zwrot, którym - nieco nadużywam niniejszym rozpoznań Ulickiej - wschodnioeuropejskie literaturoznawstwo skolonializowało się na skutek wtórnego odnalezienia własnych odkryć (przypominam: Derrida pokazał nam wespół z Kristevą naszego Bachtina, Kuhn Ludwika Flecka itd.), spowodował uwyraźnienie wszystkich tych wątków, które już w nim istniały. Bo identyfikacja istniała w nim od zarania: już Borowski wzywał Szczucką i zresztą wszystkich autorów świadectw Zagłady, żeby „opowiedzieli, co robili", zamiast chować się za narodową czy inną mitologią, ale i Sławiński w swojej obiektywizującej instrukcji „wyzbywania się uczuciowego zobowiązania” pokazywał wyraźnie, że skoro czegoś się trzeba wyzbyć, to przecież jest w tym pisarstwie jakiś specjalny imperatyw identyfikacji i, tym samym, coś szczególnego, co odróżnia (choć nie powinno) tę dziedzinę badań od innych. I nawet jeśli ostatecznie uznać, że ta polifoniczność przekształciła tylko swą nazwę na intertekstualność, a literaturoznawstwo wojny i okupacji - na Holocaust studies, to nie zmienia to faktu, że jest to akt nazwania będący jednocześnie aktem stworzenia. Mówiąc krótko: polskie literaturoznawstwo zajmowało się literaturą Zagłady od dawna, ale stało się literaturoznawstwem zagładowym dopiero wtedy, gdy nawałnica kolejnych zwrotów wyłoniła je z pozornie monolitycznych badań nad literaturą w ogóle - gdy na istniejące już struktury epistemologiczne nałożyło dyscyplinarne ramy, wiążące ten nurt badań gdzie indziej. Czyli: gdy się dobrowolnie akademicko skolonializowało. 
